\title{
Distribution of 2,3-Diaminohexuronic Acid in Strains of Propionibacterium and Other Bacteria
}

\author{
CECIL S. CUMMINS \\ Department of Anaerobic Microbiology, Virginia Polytechnic Institute and State University, Blacksburg, Virginia 24061
}

\begin{abstract}
Trichloroacetic acid extracts of 119 strains of bacteria were examined by thin-layer chromatography for the presence of 2,3-diamino-2,3-dideoxyhexuronic acid. This compound was identified by thin-layer chromatography as material giving a distinctive blue spot with a ninhydrin-collidine reagent and moving to the same position as authentic 2,3-diamino-2,3-dideoxyglucuronic acid. Material of this kind was found in all strains of propionibacteria except Propionibacterium freudenreichii and also in some strains of Clostridium, Actinomyces, and Arachnia. It was not found in representatives of Corynebacterium (11 strains), Bacillus (4 strains), Lactobacillus (11 strains), Staphylococcus (3 strains), Nocardia (3 strains), Streptomyces (1 strain), Actinoplanes (1 strain), Erysipelothrix (1 strain), Peptostreptococcus (2 strains), and Arcanobacterium (1 strain), but was present in one of the four strains of Eubacterium examined and in one of two strains of Bifidobacterium. It was not present in whole cells or lipopolysaccharides of seven strains of Bacteroides, but was found in two of five Pseudomonas aeruginosa strains tested.
\end{abstract}

A new type of aminohexuronic acid, 2,3-dideoxy-2,3diaminoglucuronic acid, was recently found in the cell wall polysaccharide of a strain of Propionibacterium acnes (6). An identical or very similar substance was also found in the cell wall polysaccharides of strains of Propionibacterium avidum and Propionibacterium granulosum. Other 2,3diamino-2,3-dideoxyhexuronic acids have been reported from the polysaccharides of Pseudomonas aeruginosa strains $(7,10,11)$. Since the substance from Propionibacterium acnes was easily recognized on thin-layer chromatograms because of the bright blue color which it gave with a ninhydrin-collidine reagent, it appeared to have the makings of a good taxonomic marker. Therefore, it seemed of interest to examine the distribution of this compound in strains of classical propionibacteria isolated from dairy products and in other bacteria.

\section{MATERIALS AND METHODS}

Strains of bacteria. The strains of bacteria used are listed in Table 1.

Conditions of growth. Most strains were grown for $48 \mathrm{~h}$ in Trypticase-yeast extract-glucose broth containing $0.1 \%$ Tween 80 . However, for corynebacteria, $5 \%$ sterile rabbit serum was added to the medium. Strains of Actinomyces israelii, Actinomyces bovis, and Actinomyces naeslundii were also grown in 5\% serum broth, usually for 5 to 6 days because of their slower rate of growth. The classical propionibacteria were grown at 30 to $33^{\circ} \mathrm{C}$; the other organisms were grown at 35 to $36^{\circ} \mathrm{C}$.

Pathogenic organisms, such as Corynebacterium diphtheriae, were killed by adding Formalin to a final concentration of $2 \%$; other organisms were killed by heating at $56^{\circ} \mathrm{C}$ for $30 \mathrm{~min}\left(70^{\circ} \mathrm{C}\right.$ in the case of staphylococci). All suspensions were washed three times in distilled water before extraction.

Cell wall fractions. Cell wall fractions were prepared as described previously by Cummins and Johnson (4).

TCA extraction. The material to be hydrolyzed was prepared by trichloroacetic acid (TCA) extraction of either whole cells or cell walls.

(i) Extraction of whole cells. Preliminary experiments with known positive strains established that $25 \mathrm{mg}$ (dry weight) of lyophilized whole cells extracted three times with $1 \mathrm{ml}$ of
$10 \%$ TCA $\left(56\right.$ to $60^{\circ} \mathrm{C}$ for $30 \mathrm{~min}$ ) gave adequate amounts of material for examination. After each extraction, the mixture was centrifuged for $1 \mathrm{~min}$ at $13,000 \times g$ with a Fisher microfuge, the supernatant was removed, and the deposit was extracted with $1 \mathrm{ml}$ of $10 \%$ TCA. Finally, the combined extracts were mixed with 5 volumes of acetone and a few drops of a $5 \%$ potassium acetate solution, and these preparations were allowed to stand overnight at $4^{\circ} \mathrm{C}$. The precipitated material was recovered by centrifugation and dissolved in $1 \mathrm{ml}$ of distilled water, and any insoluble material was removed by centrifugation at $13,000 \times g$. The supernatant was then hydrolyzed (see below).

If freshly grown material was used, the washed cells from 25 to $100 \mathrm{ml}$ of medium were extracted as described above.

(ii) Extraction of cell walls. A $10-\mathrm{mg}$ portion of cell walls was extracted by the method described above for whole cells.

(iii) Extraction of lipopolysaccharide. The hot phenol method of Luderitz et al. (15) was used to extract lipopolysaccharide from lyophilized cell walls.

Hydrolysis of extracts. The clear extract $(1 \mathrm{ml})$ after the final centrifugation was added to $1 \mathrm{ml}$ of concentrated $\mathrm{HCl}$, and the mixture was hydrolyzed for $18 \mathrm{~h}$ at $100^{\circ} \mathrm{C}$ in a sealed tube. If large amounts of humin formed, this was removed by centrifugation, and the supernatant was evaporated to dryness and taken up in about $0.2 \mathrm{ml}$ of distilled water; if necessary, the solution. was centrifuged again to remove insoluble material. For hydrolysis of lipopolysaccharide 10 $\mathrm{mg}$ of lipopolysaccharide was heated in $1 \mathrm{ml}$ of $6 \mathrm{~N} \mathrm{HCl}$ for $18 \mathrm{~h}$ at $100^{\circ} \mathrm{C}$ and then treated as described above.

Thin-layer chromatography. (i) One-dimensional chromatography. One-dimensional chromatography was performed on Avicel cellulose plates $(20$ by $20 \mathrm{~cm}$; Fisher Scientific Co.) by using one or more of the following solvents: ethyl acetate-pyridine-acetic acid-Water (72:72:14:42) (solvent A); butanol-acetic acid-Water (160:40:67) (solvent B); and $\alpha$ picoline-water-28\% $\mathrm{NH}_{4} \mathrm{OH}$ (140:56:4) (solvent $\mathrm{C}$ ). In all cases plates were developed twice in the solvent and dried at room temperature in a hood for $30 \mathrm{~min}$ between ascents. Approximately $5 \mu \mathrm{l}$ of each sample was applied on a line 3 $\mathrm{cm}$ from the bottom of the plate, and the solvent was normally run to within $2 \mathrm{~cm}$ of the top on each ascent. After the second development the plates were again dried, and the 
TABLE 1. Occurrence of 2,3-diamino-hexuronic acids (2,3-DH) in TCA extracts ${ }^{a}$

\begin{tabular}{|c|c|c|c|c|}
\hline Organism & VPI & Other & $\begin{array}{c}\text { Material examined } \\
(\mathrm{CW}, \mathrm{WC}, \mathrm{P} . \mathrm{LPS})\end{array}$ & $\begin{array}{c}\text { Presence of } \\
2,3-\mathrm{DH}\end{array}$ \\
\hline 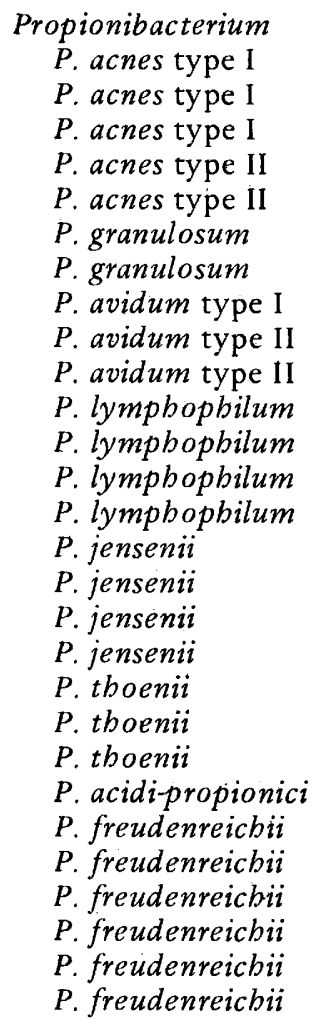 & $\begin{array}{l}0009 \\
3706 \\
6636 \\
0162 \\
0204 \\
0507 \\
6500 \\
0575 \\
0589 \\
0202 \\
0383 \\
\\
\\
0398 \\
5166 \\
5169 \\
5173 \\
0411 \\
5164 \\
5174 \\
0399 \\
0392 \\
0404 \\
0405 \\
0406 \\
0407 \\
5165\end{array}$ & $\begin{array}{c}\text { Prevot } 3109 \\
\\
\text { Prevot } 2444 \\
\text { Prevot } 578 \\
\text { Prevot } 329 \mathrm{~B}_{\mathrm{T}} \\
\text { ATCC } 25564^{\mathrm{T}} \\
\text { Prevot } 3085 \\
\text { CDC } 71 \\
\text { CDC A518 } \\
\text { London Hospital } 4982 \\
\text { Prevot } 1519 \mathrm{~F} \\
\text { Prevot SB } \\
\text { BW } 6294 \\
\text { BW } 6295 \\
\text { ATCC } 4869 \\
\text { ATCC ISL106 } \\
\text { ATCC } 4870 \\
\text { ATCC } 4964 \\
\text { ATCC } 4872 \\
\text { ATCC ISL104 } \\
\text { ATCC } 4874 \\
\text { ATCC } 25562 \\
\text { IAM } 1714 \\
\text { ATCC } 8262 \\
\text { ATCC } 9614 \\
\text { ATCC } 9614 \\
\text { ATCC } 9616 \\
\text { ATCC ISL105 }\end{array}$ & $\begin{array}{l}\text { CW, P } \\
\mathrm{CW} \\
\mathrm{CW} \\
\mathrm{CW} \\
\mathrm{CW} \\
\mathrm{CW} \\
\mathrm{CW} \\
\mathrm{CW} \\
\mathrm{CW} \\
\mathrm{CW} \\
\mathrm{CW}, \mathrm{P} \\
\mathrm{CW} \\
\mathrm{WC} \\
\mathrm{WC} \\
\mathrm{CW}, \mathrm{P} \\
\mathrm{WC} \\
\mathrm{WC} \\
\mathrm{WC} \\
\mathrm{CW}, \mathrm{P} \\
\mathrm{WC} \\
\mathrm{WC} \\
\mathrm{CW}, \mathrm{P} \\
\mathrm{WC} \\
\mathrm{WC} \\
\mathrm{WC} \\
\mathrm{WC} \\
\mathrm{CW}, \mathrm{P} \\
\mathrm{WC}\end{array}$ & $\begin{array}{l}+ \\
+ \\
+ \\
+ \\
+ \\
+ \\
+ \\
+ \\
+ \\
+ \\
+ \\
+ \\
+ \\
+ \\
+ \\
+ \\
+ \\
+ \\
+ \\
+ \\
+ \\
+ \\
+ \\
- \\
- \\
- \\
- \\
-\end{array}$ \\
\hline $\begin{array}{l}\text { Aracbnia } \\
\text { A. propionica } \\
\text { A. propionica } \\
\text { A. propionica } \\
\text { A. propionica } \\
\text { A. propionica } \\
\text { A. propionica }\end{array}$ & $\begin{array}{l}0026 \\
5067 \\
5068 \\
5069 \\
5070 \\
5074\end{array}$ & $\begin{array}{c}\text { ATCC } 14157^{\mathrm{T}} \\
\text { ATCC } 29326 \text { (WVU 346) } \\
\text { ATCC } 29324 \text { (WVU 427) } \\
\text { ATCC } 29325 \text { (WVA 439A) } \\
\text { WVU } 445 \\
\text { WVU } 572\end{array}$ & $\begin{array}{l}\mathrm{CW} \\
\mathrm{CW} \\
\mathrm{CW} \\
\mathrm{CW} \\
\mathrm{CW} \\
\mathrm{CW}\end{array}$ & $\begin{array}{l}+ \\
+ \\
+ \\
- \\
+ \\
+\end{array}$ \\
\hline $\begin{array}{l}\text { Actinomyces } \\
\quad \text { A. israelii } \\
\text { A. israelii } \\
\text { A. israelii } \\
\text { A. bovis } \\
\text { A. bovis } \\
\text { A. bovis } \\
\text { Actino. sp. } \\
\text { A. pyogenes } \\
\text { A. pyogenes } \\
\text { A. naeslundii }\end{array}$ & & $\begin{array}{l}\text { C153, ATCC } 12104 \\
\text { C276, ATCC } 10048 \\
\text { 'Flynn' London Hosp. } \\
\text { ATCC } 13683 \text { (Pine, P1) } \\
\text { Pine A11 } \\
\text { Pine A12 } \\
\text { Holm } 1452 \\
\text { NCTC } 5224 \\
\text { ATCC } 19411 \mathrm{~T} \\
\text { ATCC } 13683\end{array}$ & $\begin{array}{l}\mathrm{CW} \\
\mathrm{CW} \\
\mathrm{CW} \\
\mathrm{CW} \\
\mathrm{CW} \\
\mathrm{CW} \\
\mathrm{CW} \\
\mathrm{CW} \\
\mathrm{CW} \\
\mathrm{CW}\end{array}$ & $\begin{array}{l}+ \\
+ \\
+ \\
- \\
- \\
- \\
- \\
- \\
- \\
-\end{array}$ \\
\hline $\begin{array}{l}\text { Arcanobacterium } \\
\quad \text { A. bemolyticum }\end{array}$ & & $\mathrm{C} 27$ & $\mathrm{CW}$ & - \\
\hline $\begin{array}{l}\text { Bacillus } \\
\quad \text { B. spbaericus } \\
\text { B. licbeniformis } \\
\text { B. polymyxa } \\
\text { B. subtilis }\end{array}$ & $\begin{array}{l}5970 \\
5972 \\
5974\end{array}$ & $\begin{array}{c}\text { C1; NCTC } 2608 \\
\text { ATCC } 14580^{\mathrm{T}} \\
\text { ATCC } 842^{\mathrm{T}} \\
\text { ATCC } 6051^{\mathrm{T}}\end{array}$ & $\begin{array}{l}\text { WC } \\
\text { WC } \\
\text { WC } \\
\text { WC }\end{array}$ & $\begin{array}{l}- \\
- \\
-\end{array}$ \\
\hline
\end{tabular}


TABLE 1. Continued

\begin{tabular}{|c|c|c|c|c|}
\hline \multirow{2}{*}{ Organism } & \multicolumn{2}{|c|}{ Culture number } & \multirow{2}{*}{$\begin{array}{l}\text { Material examined } \\
(\mathrm{CW}, \mathrm{WC}, \mathrm{P}, \mathrm{LPS})\end{array}$} & \multirow{2}{*}{$\begin{array}{c}\text { Presence of } \\
2,3-\mathrm{DH}\end{array}$} \\
\hline & VPI & Other & & \\
\hline \multicolumn{5}{|l|}{ Lactobacillus } \\
\hline L. catenaforme & 0118 & PIP 3016C & $\mathrm{CW}$ & - \\
\hline L. catenaforme & 2933 & $\operatorname{ATCC} 25536^{\mathrm{T}}$ & $\mathrm{CW}$ & - \\
\hline L. catenaforme & 3091 & PIP 1792 & $\mathrm{CW}$ & - \\
\hline L. crispatus & 0253 & PIP 1409 & $\mathrm{CW}$ & - \\
\hline L. acidopbilus & 1294 & ATCC 33199 & $\mathrm{CW}$ & - \\
\hline L. acidopbilus & 1754 & ATCC 33198 & $\mathrm{CW}$ & - \\
\hline L. acidopbilus & 1784 & & CW & - \\
\hline L. acidopbilus & 6032 & $\operatorname{ATCC} 4356^{\mathrm{T}}$ & $\mathrm{CW}$ & - \\
\hline L. acidopbilus & 6033 & ATCC 19992 & $\mathrm{CW}$ & - \\
\hline L. acidopbilus & 7960 & ATCC 33200 & $\mathrm{CW}$ & - \\
\hline L. fermentum & 8153 & & WC & - \\
\hline \multicolumn{5}{|l|}{ Clostridium } \\
\hline C. botulinum A & 3800 & & $\mathrm{CW}$ & + \\
\hline C. botulinum B & 1624 & ATCC 7948 & CW & + \\
\hline C. botulinum B & 2129 & PIP 29 & $\mathrm{CW}$ & + \\
\hline C. botulinum $\mathrm{C}$ & 1615 & ATCC 9633 & CW & \pm \\
\hline C. botulinum C & 3802 & & CW & \pm \\
\hline C. botulinum $\mathrm{C}$ & 3804 & & $\mathrm{CW}$ & $\overrightarrow{+}$ \\
\hline C. botulinum $\mathrm{D}$ & 1543 & CDC KA 39 & $\mathrm{CW}$ & + \\
\hline C. botulinum $\mathrm{D}$ & 3805 & & $\mathrm{CW}$ & \pm \\
\hline C. sporogenes & 2737 & & $\mathrm{CW}$ & + \\
\hline C. tertium & 1565 & ATCC 14573 & $\mathrm{CW}$ & + \\
\hline C. tertium & 2033 & CDC 481 & $\mathrm{CW}$ & + \\
\hline C. novyi & 1617 & ATCC 898 & $\mathrm{CW}$ & $\operatorname{Tr}$ \\
\hline C. novyi & 4258 & McClung 117 & $\mathrm{CW}$ & $\mathrm{Tr}$ \\
\hline C. perfringens & 1537 & CDC KA 3 & $\mathrm{CW}$ & - \\
\hline C. perfringens & 5694 & $\operatorname{ATCC} 13124^{\mathrm{T}}$ & CW & - \\
\hline C. butyricum & 1718 & ATCC 860 & CW & + \\
\hline C. butyricum & 2983 & Prevot A9E1 & $\mathrm{CW}$ & + \\
\hline C. beijerinckii & 4420 & ATCC 17778 & $\mathrm{CW}$ & + \\
\hline C. acetobutylicum & 3163 & ATCC $824^{T}$ & $\mathrm{CW}$ & - \\
\hline C. innocuum & 2581 & & $\mathrm{CW}$ & - \\
\hline C. putrificum & 4440 & ATCC $25784^{\mathrm{T}}$ & $\mathrm{CW}$ & - \\
\hline C. paraputrificum & 1584 & $\operatorname{ATCC} 25780^{\mathrm{T}}$ & $\mathrm{CW}$ & - \\
\hline C. paraputrificum & 1586 & CDC 391 & CW & - \\
\hline C. tetani & 1609 & ATCC 8033 & $\mathrm{CW}$ & - \\
\hline C. pasteurianum & 4215 & ATCC $6013^{\mathrm{T}}$ & $\mathrm{CW}$ & - \\
\hline C. limosum & 1748 & PIP 666 & $\mathrm{CW}$ & + \\
\hline C. limosum & 1950 & CDC 1218 & $\mathrm{CW}$ & + \\
\hline C. limosum & 1740 & CDC 1402 & $\mathrm{CW}$ & - \\
\hline C. limosum & 1928 & CDC 719 & CW & - \\
\hline C. limosum & 2755 & PIP 278 & $\mathrm{CW}$ & + \\
\hline Clostridium $\mathrm{sp}$ & 3160 & FDA S9 & CW & + \\
\hline Clostridium sp. & $2808 \mathrm{~A}$ & & CW & - \\
\hline \multicolumn{5}{|l|}{ Staphylococcus } \\
\hline S. aureus & $19 \mathrm{a}$ & & CW & - \\
\hline S. aureus & $2 a$ & & WC & - \\
\hline S. epidermidis & & Biology Dept., VPI \& SU & WC & - \\
\hline \multicolumn{5}{|l|}{ Peptostreptococcus } \\
\hline P. magnus & 5467 & PIP 1469B & WC & - \\
\hline P. glycinopbilus & 5664 & $\operatorname{ATCC} 23195^{\mathrm{T}}$ & WC & - \\
\hline \multicolumn{5}{|l|}{ Bifidobacterium } \\
\hline B. asteroides & 5636 & $\operatorname{ATCC} 25910^{\mathrm{T}}$ & WC & + \\
\hline B. adolescentis & 5640 & Scardovi C410 & WC & - \\
\hline
\end{tabular}


TABLE 1. Continued

\begin{tabular}{|c|c|c|c|c|}
\hline Organism & VPI & Alture number & $\begin{array}{c}\text { Material examined } \\
\text { (CW, WC, P, LPS) }\end{array}$ & $\begin{array}{c}\text { Presence of } \\
\text { 2,3-DH }\end{array}$ \\
\hline \multicolumn{5}{|l|}{ Eubacterium } \\
\hline E. limosum & 5167 & ATCC $8486_{T}^{1}$ & WC & - \\
\hline E. lentum & 0255 & ATCC $25559^{1}$ & WC & - \\
\hline E. lentum & 8251 & & WC & + \\
\hline E. lentum & 10290 & & WC & - \\
\hline \multicolumn{5}{|l|}{ Erysipelotbrix } \\
\hline E. rbusiopatbiae & & Coll. of Vet. Med., VPI \& SU & WC & - \\
\hline \multicolumn{5}{|l|}{ Corynebacterium } \\
\hline C. dipbtberiae & & C122 & WC & - \\
\hline C. diphtberiae & & C123 & WC & - \\
\hline "C. ulcerans" & & C102, NCTC 7910 & WC & - \\
\hline "C. ovis" & & C103, NCTC 3450, ATCC 19410 & WC & - \\
\hline C. xerosis & & C105, NCTC 9735 & WC & - \\
\hline C. renale & & C104, NCTC 7448, ATCC $19412^{\mathrm{T}}$ & WC & - \\
\hline "C. equi" & & C101, NCTC 1621 & WC & - \\
\hline C. bovis & & ATCC $7715^{\mathrm{T}}$ & WC & - \\
\hline C. paurometabolv & & $\operatorname{ATCC~} 8368^{\mathrm{T}}$ & WC & - \\
\hline C. minutissimum & & 1130 & WC & - \\
\hline C. minutissimum & & 771 & WC & - \\
\hline \multicolumn{5}{|c|}{ Nocardias and Streptomycetes } \\
\hline Nocardia sp. & & C132, Rutgers 736B & WC & - \\
\hline N. autotropbica & & 6031 & WC & - \\
\hline N. mediterranei & & 6030 & WC & - \\
\hline S. coelicolor & & 186 & WC & - \\
\hline Actinoplanes mis & ensis & 5375 & WC & - \\
\hline \multicolumn{5}{|l|}{ Bacteroides } \\
\hline B. fragilis & 2553 & ATCC $25285^{1}$ & WC & - \\
\hline B. fragilis & 2552 & NCTC 8560 & WC & - \\
\hline B. vulgatus & 4245 & ATCC $8482^{\mathrm{T}}$ & WC & - \\
\hline B. ovatus & 0038 & $\operatorname{ATCC} 8483^{\mathrm{T}}$ & WC & - \\
\hline "3452-A" group & 3452 & & WC & - \\
\hline B. fragilis & 2393 & PIP Beerens 12 & P, LPS & - \\
\hline B. fragilis & 5482 & NCTC 10582 & LPS & - \\
\hline \multicolumn{5}{|l|}{ Pseudomonas } \\
\hline \multirow[t]{5}{*}{$P$. aeruginosa } & & ATCC 15152 (NCTC 1999) & LPS & - \\
\hline & & ATCC 27314 (Habs Type 3) & WC & - \\
\hline & & ATCC 27315 (Habs Type 4) & WC & ++ \\
\hline & & ATCC 27578 (Habs Type 5) & WC & - \\
\hline & & ATCC 27586 (Habs Type 1$)$ & WC & ++ \\
\hline
\end{tabular}

${ }^{a}$ Abbreviations used $:-$ TCA $=$ Trichloroacetic acid $; \mathrm{CW}=$ cell walls $; \mathrm{WC}=$ whole cells $; \mathrm{P}=$ cell wall polysaccharide ; LPS = Lipopolysaccharide; 2,3-DG = 2,3-diamino-2,3-dideoxyglucuronic acid; VPI \& SU = Virginia Polytechnic Institute and State University; BW = Burroughs Wellcome; PIP = Pasteur Institute Paris; ATCC = American Type Culture Collection; CDC = Communicable Disease Center, Atlanta, Ga.; NCTC = National Collection of Type Cultures, Colindale, England. For Pseudomonas aeruginosa types, see references 1, 8, and 14.

spots were visualized by spraying with the following mixture: $50 \mathrm{mg}$ of ninhydrin in $50 \mathrm{ml}$ of $95 \%$ ethanol containing $10 \mathrm{ml}$ of glacial acetic acid and $1 \mathrm{ml}$ of collidine $(2,4,6-$ trimethylpyridine) (formula slightly modified from that of Cowgill and Pardee [3]). To develop the spots, the plates were heated in an oven at $90^{\circ} \mathrm{C}$ for exactly $3 \mathrm{~min}$. This temperature and time were adhered to because overheating was found to obscure the distinctive bright blue color of 2,3-diaminoglucuronic acid. (ii) Two-dimensional chromatography. Two-dimensional chromatography was performed on Avicel cellulose plates by using a single ascent in solvent $\mathrm{B}$ in the first dimension, followed by two ascents in solvent $C$ in the second dimension. The plates were dried overnight after the first solvent, and for $1 \mathrm{~h}$ between the two ascents in the second solvent.

The spots were visualized by the ninhydrin-collidine reagent described above for one-dimensional chromatography. 


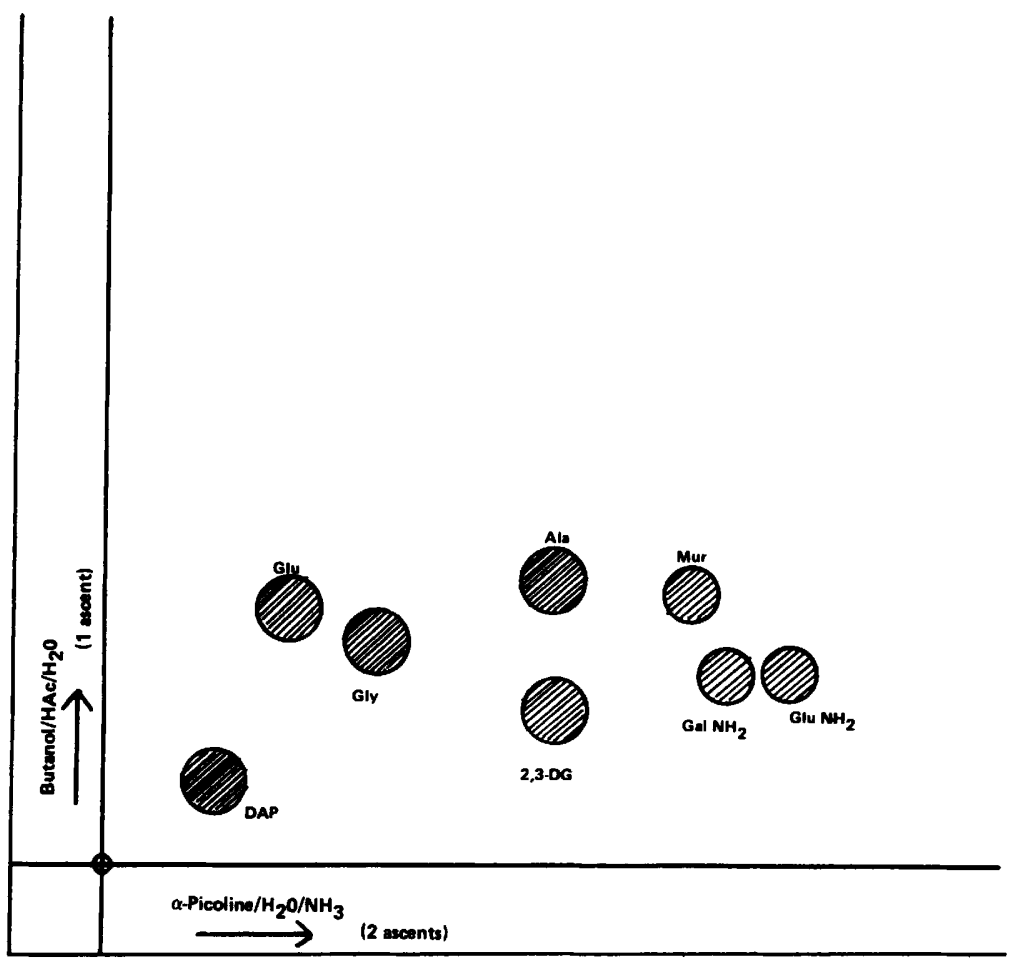

FIG. 1. Separation of 2,3-diamino-2,3-dideoxyglucuronic acid from other amino sugars and peptidoglycan components. Abbreviations: Ala, alanine; DAP, diaminopimelic acid; $\mathrm{GalNH}_{2}$, galactosamine; $\mathrm{GluNH}_{2}$, glucosamine; Glu, glutamic acid; Gly, glycine; Mur, muramic acid; 2,3-DG, 2,3-diamino-2,3-dideoxyglucuronic acid; HAc, acetic acid.

\section{RESULTS AND DISCUSSION}

The primary purpose of this investigation was to establish whether 2,3-diamino-2,3-dideoxyglucuronic acid is confined to Propionibacterium acnes and other cutaneous propionibacteria or whether it also occurs in the classical propionibacteria from cheese and dairy products. Since a variety of cell wall preparations were available from previous investigations on members of other genera, these were also examined. In addition, extracts of whole cells of a limited number of other species were analyzed. Since 2,3diaminoglucuronic acid was originally described in polysaccharides extracted from the cell walls of Propionibacterium acnes by using $10 \% \mathrm{TCA}$ at 56 to $60^{\circ} \mathrm{C}$, my investigations were essentially limited to material extracted from other organisms by a similar method, except in three cases where lipopolysaccharide was used. Whenever TCA extracts of whole cells and of cell walls from the same organism were compared, the results were identical, suggesting that if the substance is present in the wall polysaccharide, it can readily be detected also in TCA extracts of whole cells. Long storage (up to 12 years) did not appear to affect the amount of 2,3-diamino-2,3-dideoxyhexuronic acid that could be detected when extracts of old samples were compared with extracts of fresh cell walls.

At the time that 2,3-diamino-2,3-dideoxyhexuronic acid was first isolated and identified in the cell wall polysaccharide of Propionibacterium acnes (6), I was not aware that an apparently identical substance had been described by Knirel et al. (10) from the lipopolysaccharide of Pseudomonas aeruginosa. Subsequently, Knirel et al. (11), Dmitriev et al. (7), and Okuda and Suzuki (16) described other strains of Pseudomonas which contained the acetyl derivatives of 2,3-diamino-2,3-dideoxymannuronic acid and 2,3-diamino- 2,3-dideoxyguluronic acid or 2,3-diamino2,3 -dideoxyglucofuranurono-6,3-lactam $(16,17)$. In the present investigations five strains of Pseudomonas aeruginosa were examined, four of them as TCA extracts of whole cells and one as lipopolysaccharide. Two of these strains were found to contain large amounts of material giving the same color and running to the same position as 2,3-diamino-2,3dideoxyglucuronic acid from Propionibacterium acnes.

So far, it has not been possible to obtain and examine the strains investigated by Knirel et al. $(7,10-13)$ and to compare directly the chromatographic behaviors of the different diaminohexuronic acids. Knirel et al. (7, 10-13) reported 2,3-diaminoguluronic acid in a strain of Pseudomonas aeruginosa belonging to Habs serotype 5, but the strain of Habs group 5 examined in the present investigation (strain ATCC 27578) contained no blue-spot material of any kind.

Chemical identity of the blue-spot material. With the solvents used, especially in two-dimensional thin-layer chromatography, the substance giving the distinctive blue spot was well separated from other amino acids and amino sugars (Fig. 1). However, except in the case of Propionibacterium acnes VPI 0009, from which it was originally isolated (6), the material was not separated and identified chemically. In all strains in which it was found, the compound ran to the same position as authentic 2,3-diamino-2,3-dideoxyglucuronic acid. This may mean either that the same 2,3-diamino-2,3dideoxyhexuronic acid occurs in all cases or that all of the diaminohexuronic acids that occur in these strains have identical chromatographic properties in the solvents.

As noted above, various other 2,3-diamino2,3-dideoxyhexuronic acids have been identified by ${ }^{13} \mathrm{C}$ nuclear magnetic resonance spectroscopy in the polysaccharides of Pseudomonas aeruginosa $(7,10-13,16)$ and may well occur in the polysaccharides of other organisms as well. 
It seems reasonable to assume that they have very similar chromatographic properties, but this has not yet been proven.

Distribution of 2,3-diamino-2,3-dideoxyhexuronic acids. In all, extracts of 119 strains of bacteria were examined. It appears that 2,3-diamino-2,3-dideoxyhexuronic acid is a rather characteristic feature of the cell wall polysaccharides of propionibacteria, with the striking (and perhaps unfortunate) exception of the type species, Propionibacterium freudenreichii. This is another illustration of the fact that Propionibacterium freudenreichii is a somewhat atypical species in the genus (5). Apparently identical material was also found in seven of eight strains of Arachnia propionica, which appear to have a metabolic pattern similar to that of propionibacteria, although they show no relationship to propionibacteria by deoxyribonucleic acid homology (9).

In Clostridium the material was present in a number of species. In Clostridium botulinum (types A, B, C, and D) the amount present varied considerably although the same weight of cell walls was extracted in each case; this may have been due to its being part of a polymer which occurs in different amounts in different strains. The occurrence of 2,3-diamino-2,3-dideoxyhexuronic acids in such diverse groups as propionibacteria, actinomyces, pseudomonads, and clostridia suggests that the presence of these compounds is not associated with any particular type of metabolism. Preliminary experiments with a few strains of capsulated propionibacteria (Propionibacterium jensenii and Propionibacterium thoenii) showed that diaminohexuronic acids are absent from the capsular material even though they are present in the cell wall polysaccharides of the same strains. They were not found in purified peptidoglycan from propionibacteria (i.e., cell walls after extraction with TCA and hot formamide) (Cummins, unpublished data). Therefore, in bacteria these substances appear to be particularly associated with cell wall polysaccharides. Their patchy distribution makes it unlikely that they play a general role in cell wall structure as, for example, muramic acid does in peptidoglycan. They could possibly act as linking agents between polysaccharide and peptidoglycan in cases where the polysaccharide lacks other suitable groups, such as phosphate.

The limited distribution and unusual color reaction of 2,3-diamino-2,3-dideoxyhexuronic acids with ninhydrin suggest that they may be of value in systematic surveys of chemical composition as applied to taxonomy.

\section{ACKNOWLEDGMENTS}

I thank T. D. Wilkins, J. L. Johnson, W. E. C. Moore, and R. H. White for comments on the manuscript and Patrick Hall for technical assistance. I also thank C. F. Hirsh, Merck Institute for Therapeutic Research, for strains of Nocardia and Streptomyces. I thank one of the reviewers for suggesting additional references.

This work was funded by the Jeffress Foundation and by the Commonwealth of Virginia.

\section{LITERATURE CITED}

1. Brokopp, C. D., and J. J. Farmer. 1979. Typing methods for Pseudomonas aeruginosa, p. 89-133. In R. Doggett (ed.), Pseudomonas aeruginosa; clinical manifestations of infection and current therapy. Academic Press, Inc., New York.

2. Cato, E. P., C. S. Cummins, and L. DS. Smith. 1970. Clostridium limosum André in Prévot 1948, 165: amended description and pathogenic characteristics. Int. J. Syst. Bacteriol. 20:305-316.

3. Cowgill, R. W., and A. B. Pardee. 1957. Experiments in biochemical research techniques. John Wiley \& Sons, Inc., New York.

4. Cummins, C. S., and J. L. Johnson. 1971. Taxonomy of the clostridia: wall composition and DNA homologies in Clostridium butyricum and other butyric acid-producing clostridia. J. Gen. Microbiol. 80:433-442.

5. Cummins, C. S., and J. L. Johnson. 1981. The genus Propionibacterium, p. 1894-1902. In M. P. Starr, H. Stolp, H. G. Truper, A. Balows and H. G. Schlegel (ed.), The prokaryotes. Springer-Verlag, Berlin.

6. Cummins, C. S., and R. H. White. 1983. Isolation, identification, and synthesis of 2,3-diamino-2,3-dideoxyglucuronic acid: a component of Propionibacterium acnes cell wall polysaccharide. J. Bacteriol. 153:1388-1393.

7. Dmitriev, B. A., N. A. Kocharova, Y. A. Knirel, A. S. Shaskov, N. K. Kochetkov, E. S. Stanislavsky, and G. M. Mashilova. 1982. Somatic antigens of Pseudomonas aeruginosa: the structure of the polysaccharide chain of Ps. aeruginosa 0:6 (Lanyi) polysaccharide. Eur. J. Biochem. 125:229-237.

8. Habs, I. 1957. Untersuchungen über die O-antigene von Pseudomonas aeruginosa. Z. Hyg. Infektionskr. 144:218-228.

9. Johnson, J. L., and C. S. Cummins. 1972. Cell wall composition and deoxyribonucleic acid similarities among the anaerobic coryneforms, classical propionibacteria, and strains of Arachnia propionica. J. Bacteriol. 109:1047-1066.

10. Knirel, Y. A., N. A. Kocharova, A. S. Shashkov, B. A. Dmitriev, and N. K. Kochetkov. 1981. 2,3-Diacetamido-2,3-dideoxy-Dglucuronic acid: a new acidic amino sugar from Pseudomonas aeruginosa type 06 lipopolysaccharide. Carbohydr. Res. 93: $\mathrm{C} 12-\mathrm{C} 13$.

11. Knirel, Y. A., E. V. Vinogradov, A. S. Shashkov, B. A. Dmitriev, and N. K. Kochetkov. 1982. 2,3-Diacetamido-2,3-dideoxy-Dmannuronic acid and its 2-imidazoline derivative: new acidic amino sugars from Pseudomonas aeruginosa O:3a,d lipopolysaccharide. Carbohydr. Res. 104:C4-C7.

12. Knirel, Y. A., V. Vinogradov, A. S. Shaskov, B. A. Dmitriev, N. K. Kochetkov, E. S. Stanislavsky, and G. M. Mashilova. 1983. Somatic antigens of Pseudomonas aeruginosa: the structure of $\mathrm{O}$-specific polysaccharide chains of $P$ s. aeruginosa $\mathrm{O}: 3 \mathrm{a}, \mathrm{b}$ and O:3a,d lipopolysaccharides. Eur. J. Biochem. 128:81-90.

13. Knirel, Y. A., V. Vinogradov, A. S. Shaskov, B. A. Dmitriev, N. K. Kochetkov, E. S. Stanislavsky, and G. M. Mashilova. 1983. Somatic antigens of Pseudomonas aeruginosa: the structure of O-specific polysaccharide chains of $P$ s. aeruginosa $0: 3(\mathrm{a}), \mathrm{c}$ and O:3a,d,e lipopolysaccharides. Eur. J. Biochem. 134:289-297.

14. Lanyi, B., and T. Bergan. 1978. Serological characteristics of Ps. aeruginosa, p. 93-168. In T. Bergan and J. Norris (ed.), Methods in microbiology, vol. 10. Academic Press, Inc., New York.

15. Lüderitz, O., O. Westphal, A. M. Staub, and H. Nikaido. 1971. Isolation and chemical and immunological characterization of bacterial lipopolysaccharides, p. 331-350. In G. Weinbaum, S. Kadis, and S. Ajl (ed.), Microbial toxins, vol. 4. Academic Press, Inc., New York.

16. Okuda, S., and N. Suzuki. 1983. 2,3-Diamino-2,3-dideoxy-Dfuranurono-6,3-lactam from the hydrolysate of Pseudomonas aeruginosa P14 lipopolysaccharide. Biochem. J. 215:597-604.

17. Wilkinson, S. G. 1983. Composition and structure of lipopolysaccharides from Pseudomonas aeruginosa. Rev. Infect. Dis. 5(Suppl. 55):S941-S949. 